\title{
AN ANALYSIS OF THE ROLE OF SERUM IN PARATHYROID HORMONE-INDUCED BONE RESORP- TION IN TISSUE CULTURE
}

\author{
PAULA H. STERN ${ }^{1}$ and L. G. RAISZ \\ Department of Phurmacology, University of Michigan Medical Schvol, Ann Arbor, Michigan and \\ Departments of Pharmacology and Medicine, University of Rochester School of Medicine, Rochester \\ N.Y., New York, U.S.A.
}

Received August 29, 1966

THE stimulation of bone resorption by parathyroid hormone can be quantitated in tissue cultures of embryonic bone [20], using paired limb bones from a single embryo in which radioactive calcium $\left({ }^{45} \mathrm{Ca}\right)$ has previously been incorporated. The ratio of ${ }^{45} \mathrm{Ca}$ release from the parathyroid hormonetreated bones to that from the control bones is a sensitive measure of parathyroid effect. This technique has been applied to a study of the mechanism of action of parathyroid hormone and of other factors affecting bone resorption and also has been used to assay for parathyroid hormone activity in biological fluids $[8,21-23]$. The major disadvantages of this system are the variability of the response [21] and the difficulty in analyzing for small biochemical changes. Because our preliminary observations suggested that some of these disadvantages might be ascribable to the high concentration of serum ( 50 per cent) used in the culture medium, the objective of the present study was to find the simplest and chemically best defined medium in which bone resorption could be stimulated by parathyroid hormone. Chemically defined media without serum proved to be inadequate to support parathyroid hormone-induced bone resorption; therefore the minimum serum concentration required for a parathyroid effect was determined and the constituent of serum necessary for this response identified. The critical factor occurs in the albumin fraction of serum. This fraction appears to contain a non-parathyroid factor which can both support parathyroid-stimulated bone resorption and enhance ${ }^{45} \mathrm{Ca}$ release from control bones.

\footnotetext{
${ }^{1}$ Present address: Department of Pharmacology, Northwestern University Medical School, Chicago, IIl. 60611, U.S.A.
} 


\section{METHODS}

Animals.-Details of the method have been published previously [21]. 17-daypregnant Holtzman or Rochester-Wistar rats were injected subcutaneously with $200-500 \mu \mathrm{c}$ of ${ }^{45} \mathrm{CaCl}_{2}$. These rats were sacrificed two days later, the embryos removed and the bone shafts of paired radii and ulnae cultivated in individual vessels containing $0.5 \mathrm{ml}$ of culture medium for $72 \mathrm{hr}$ at $37^{\circ} \mathrm{C}$ either in an atmosphere of 5 per cent $\mathrm{CO}_{2}$ in air, or in 5 per cent $\mathrm{CO}_{2}, 75$ per cent $\mathrm{N}_{2}$ and 20 per cent $\mathrm{O}_{2}$.

Media.-Media used in the present study included (1) Eagle Basal Medium with Earle's balanced salt solution, (2) Eagle Minimal Essential Medium with Earle's balanced salt solution, (3) Trowell T-8 medium, without chloramphenicol, (4) Waymouth MB 752/1, (5) McCoy 5A, (6) NCTC 109, and (7) 1066. The Trowell medium, which does not contain vitamins, was supplemented to bring the vitamin content equal to that in the Eagle media. In addition to the standard Waymouth MB 752/1, a modified preparation was tested. This modified medium contained an additional $19 \mu \mathrm{g} / \mathrm{ml}$ nicotinamide and $32.5 \mu \mathrm{g} / \mathrm{ml}$ ascorbic acid, and was also supplemented with $1 \mu \mathrm{g} / \mathrm{ml} a$-tocopherol and $0.5 \mathrm{mg} / \mathrm{ml}$ sodium acetate. These additions eliminated some major differences between the Waymouth MB $752 / 1$ and Biggers' medium BGJ, a chemically defined medium reported to support development of embryonic bone rudiments in vitro [3]. Two different 1066 preparations were used: one (Difco TC-Medium 1066) contained $0.1 \mathrm{~g} / \mathrm{l}$ of a porcine liver coenzyme concentrate, whereas these same coenzymes were present in a more highly purified form at a total concentration of $0.01 \mathrm{~g} / \mathrm{l}$ in the other preparation (CMRL 1066, Grand Island Biological Company, GIBCO).

Sera.- Human serum was obtained from fasting laboratory personnel or purchased from commercial sources. Rat serum was obtained by cardiac puncture from animals that had been parathyroidectomized 1 month to 1 year previously (PTX rat serum), and was not used unless the calcium concentration was below $7.0 \mathrm{mg} / 100 \mathrm{ml}$. Serum was heated at $56^{\circ}-60^{\circ} \mathrm{C}$ for $30 \mathrm{~min}$ to inactivate complement. For preparation of dialysate and residual fractions, serum was dialyzed against CMRL 1066 for $48 \mathrm{hr}$ at $4^{\circ} \mathrm{C}$ with Visking dialysis tubing. To determine the extent of calcium binding by albumin, equilibrium dialysis was performed under conditions simulating those used for incubation of the cultures $\left(72 \mathrm{hr}, 37^{\circ} \mathrm{C}, 5\right.$ per cent $\left.\mathrm{CO}_{2}\right)$.

Hormones.--Two hormone preparations were used, (1) bovine parathyroid extract, PTE, Eli Lilly Company; control bones received an equal amount of the hormone solvent ( 1.6 per cent glycerol, 0.2 per cent phenol, 0.9 per cent $\mathrm{NaCl}$ ) and (2) bovine parathyroid hormone (PTH) supplied by Dr W.Y.W. Au. The PTH had been purified by gel filtration [15] and had a potency of $2500 \mathrm{units} / \mathrm{mg}$. It was dissolved in distilled water $(40 \mu \mathrm{g} / \mathrm{ml})$; distilled water was added to control bone cultures.

Proteins.- Human and PTX rat serum albumins were prepared as described by Schwert [25]. This material has been shown to be chemically and biologically indistinguishable from native albumin excepl for a small difference in the rate of trypsin hydrolysis $[25,26]$. The following bovine serum protein fractions (Pentex) were used: (1) bovine serum albumin, fraction $V$, reported to contain 90 per cent albumin contaminated with $\alpha$ - and $\beta$-globulins, (2) a free fatty acid (FFA)-poor fraction V preparation containing less than 0.05 per cent fatty acid, (3) crystalline bovine 
serum albumin, 100 per cent pure, (4) $\alpha$-globulins, fraction IV, (5) $\beta$-globulins, fraction III and (6) $\gamma$-globulins, fraction II. The non-serum proteins also tested included: (7) crystalline ovalbumin (Worthington), (8) calf thymus histone, B grade (Calbiochem), (9) gelatin, technical (Will Corp.), (10) insulin (Iletin ${ }^{\circledR}$, Eli Lilly Co.) and (11) heparin (Heparin sodium, Nutritional Biochemicals Corp.).

Assays. - Stable calcium concentrations were measured colorimetrically in $0.1 \mathrm{ml}$ aliquots of culture fluid using Corinth Ca (Plasmacorinth B) as the complexing dye [16]. A modified biuret procedure was used to determine protein concentrations in $0.2 \mathrm{ml}$ aliquots of culture fluid [13]. ${ }^{45} \mathrm{Ca}$ was measured in an automatic liquid scintillation counter as described previously [21].

Calculations.- Results are expressed either as the ${ }^{45} \mathrm{Ca}$ release, measured as $\mathrm{cpm} /$ $0.1 \mathrm{ml}$ of the incubation medium at the end of the experiment, or as the ratio of the ${ }^{45} \mathrm{Ca}$ release from the treated bone to that from the paired control (T/C ratio). Responses were analyzed for significance with a 2 -tailed $t$ test.

\section{RESULTS}

\section{Chemically defined media}

Table I shows the effect of parathyroid hormone treatment on embryonic bone cultivated in a number of readily-available chemically-defined media. Crude parathyroid extract (PTE) failed to stimulate ${ }^{45} \mathrm{Ca}$ release in three of the media tested (Eagle Minimal Essential Medium, Trowell T-8 and Waymouth MB 752/1). With addition of cofactors to the Waymouth medium, there was a moderate response to PTE. A further increase in the response to PTE was seen with the highly complex medium 1066 containing a crude nucleotide fraction (1066, DIFCO). Less PTE effect was seen when a more highly purified 1066 preparation (CMRL 1066, GIBCO) was used. When an equivalent amount of purified parathyroid hormone (PTH) was substituted for the parathyroid extract (PTE), no hormone effect could be detected either in CMRL 1066 or in two other complex media (McCoy 5A, NCTC 109). A threefold increase in the concentration of purified $\mathrm{PTH}$ failed to restore a response.

\section{Serum concentration required to support the PTH effect}

Table II presents results of several experiments designed to determine the proportion of serum essential for maintenance of bones in culture and for an optimal PTH effect. Medium CMRL 1066 (GIBCO) was supplemented with varying quantities of PTX rat serum. Release of ${ }^{45} \mathrm{Ca}$ from the control bones was usually enhanced when the medium was supplemented with 5 per cent serum. Iower concentrations of serum had no effect on the control response. Significant PTH-induced ${ }^{45} \mathrm{Ca}$ release could be elicited in a medium con- 
'Гавце I. Parathyroid hormone-induced ${ }^{45}$ Ca release in several synthetic media.

\begin{tabular}{|c|c|c|c|c|c|c|}
\hline \multirow{2}{*}{$\begin{array}{l}\text { Exp. } \\
\text { 110. }\end{array}$} & \multirow[b]{2}{*}{ Medium } & \multirow{2}{*}{$\begin{array}{l}\text { Hormone, } \\
\text { concentration }\end{array}$} & \multirow[b]{2}{*}{$\mathrm{N}$} & \multicolumn{2}{|c|}{${ }^{45} \mathrm{Ca}$ release-cpm/0.1 ml } & \multirow{2}{*}{$\begin{array}{l}{ }^{45} \mathrm{Ca} \\
\text { release- } \\
\text { T/C ratio }\end{array}$} \\
\hline & & & & Control $(\mathrm{C})$ & Treated $(\mathrm{T})$ & \\
\hline$s-4$ & Eagle $\mathrm{YEM}$ & PTE, $1 \mathrm{U} / \mathrm{ml}$ & 2 & $67.3,50.4$ & $68.5,51.9$ & $1.02,1.01$ \\
\hline$S-4$ & Trowell T8 & P'TE, $1 \mathrm{U} / \mathrm{ml}$ & 2 & $28.6,14.1$ & $22.8,12.7$ & $0.80,0.90$ \\
\hline \multirow[t]{2}{*}{$\$-4$} & Waymouth & & & & & \\
\hline & $\operatorname{MBB} 752 / 1$ & PTE, $1 \mathrm{U} / \mathrm{ml}$ & 3 & $40 \pm 4$ & $41 \pm 7$ & $1.02 \pm 0.06$ \\
\hline$S-4$ & Waymouth & $\mathrm{PTE}, 1 \mathrm{IJ} / \mathrm{ml}$ & 3 & $47 \pm 4$ & $60 \pm 6$ & $1.28 \pm 0.11$ \\
\hline S-5 & MB $752 / 1$ & & 4 & $75 \pm \quad 5$ & $91 \pm 11$ & $1.24 \pm 0.20$ \\
\hline \multirow[t]{2}{*}{ S-6 } & plus cofactors & & 4 & $36 \pm 2$ & $66 \pm 14$ & $1.82 \pm 0.34$ \\
\hline & & & 11 & & & $1.46 \pm 0.16^{*}$ \\
\hline S -5 & 1066 & P'TE, $1 \mathrm{U} / \mathrm{ml}$ & 4 & $82 \pm 5$ & $128 \pm 20$ & $1.54 \pm 0.16^{*}$ \\
\hline$S-6$ & (DIFCO) & & 4 & $76 \pm 18$ & $173 \pm 48$ & $2.25 \pm 0.34^{*}$ \\
\hline S-10 & & & 4 & $119 \pm 15$ & $259 \pm 62$ & $2.23 \pm 0.41$ \\
\hline S-11 & & & 4 & $350 \pm 77$ & $700 \pm 264$ & $1.81 \pm 0.42$ \\
\hline \multirow[t]{2}{*}{$\mathrm{S}-12$} & & & 4 & $272 \pm 123$ & $518 \pm 89$ & $1.95 \pm 0.40^{*}$ \\
\hline & & & 20 & & & $1.97 \pm 0.15 * *$ \\
\hline S-10 & 1066 & PTE, $0.33 \mathrm{U} / \mathrm{ml}$ & 4 & $128 \pm 10$ & $209 \pm 44$ & $1.60 \pm 0.21$ \\
\hline \multirow[t]{2}{*}{$S-11$} & (1) $1 \mathrm{FCO}$ & & 4 & $227 \pm 39$ & $469 \pm 186$ & $1.76 \pm 0.52$ \\
\hline & & & 8 & & & $1.74 \pm 0.25 *$ \\
\hline 359 & $\begin{array}{l}\text { CMRL } 1066 \\
\text { (GIBCO) }\end{array}$ & $\mathrm{PTE}, 1 \mathrm{U} / \mathrm{ml}$ & 4 & $794 \pm 58$ & $1251 \pm 198$ & $1.55 \pm 0.17^{*}$ \\
\hline 359 & $\begin{array}{l}\text { CMRL } 1066 \\
\text { (GIBCO) }\end{array}$ & PTE, $0.33 \mathrm{U} / \mathrm{ml}$ & 4 & $619 \pm 61$ & $614 \perp 58$ & $1.00 \perp 0.06$ \\
\hline 352 & CMRL 1066 & $\mathrm{P} \mathrm{TH}, 0.4 \mu \mathrm{g} / \mathrm{ml}$ & 8 & $143 \pm 19$ & $176 \pm 35$ & $1.18 \pm 0.07 *$ \\
\hline 358 & $(\mathrm{GIBCO})$ & & 4 & $345+37$ & $360 \pm 48$ & $1.04 \pm 0.04$ \\
\hline 359 & & & 4 & $779 \pm 156$ & $759 \pm 199$ & $0.99 \pm 0.07$ \\
\hline S-14 & & & 4 & $356 \pm 22$ & $353 \pm 26$ & $0.99 \pm 0.06$ \\
\hline \multirow[t]{2}{*}{ S-15 } & & & 4 & $200 \pm 19$ & $194 \pm 7$ & $0.99 \pm 0.06$ \\
\hline & & & 24 & & & $1.06 \pm 0.03$ \\
\hline 352 & McCoy $5 \mathrm{~A}$ & РТH, $0.4 \mu \mathrm{g} / \mathrm{ml}$ & 4 & $96 \pm 12$ & $102 \pm 12$ & $1.08 \pm 0.10$ \\
\hline 352 & NCTC 109 & $\mathrm{PTH}, 0.4 \mu \mathrm{g} / \mathrm{ml}$ & 4 & $186 \pm 21$ & $177 \pm 24$ & $0.96 \pm 0.08$ \\
\hline \multirow[t]{2}{*}{359} & CMRL 1066 & & & & & \\
\hline & $(G I B C O)$ & РТH, $1.2 \mu \mathrm{g} / \mathrm{ml}$ & 4 & $775 \pm 225$ & $815 \pm 200$ & $1.10+0.29$ \\
\hline
\end{tabular}

Values are mean + standard error for ${ }^{45} \mathrm{Ca}$ release and for the treated/control ratios for paired bones with and without parathyroid hormone treatment.

* Value significantly different from $1.00(p<0.05)$.

** Value significantly different from $1.00(p<0.01)$. 
taining as little as 0.2 per cent serum, and the PTH effect increased with increasing serum concentrations up to 2 per cent serum (Fig. 1). The doseresponse curve obtained with PTH in medium CMRL 1066 with 2 per cent serum is shown in Fig. 2. Using Eagle's Basal Medium the response to PTH was poor in 5 per cent serum but maximal with 50 per cent serum (Fig. 1).

TABLE II. ${ }^{45} \mathrm{Ca}$ release from embryonic bone and the response to parathyroid hormone (PTH, $0.4 \mu \mathrm{g} / \mathrm{ml}$ ).

Effect of addition of small amounts of serum to CMRL 1066 .

\begin{tabular}{|c|c|c|c|c|}
\hline Exp. no. & Per cent serum & $\mathbf{N}$ & $\begin{array}{c}\text { Control } \\
{ }^{45} \text { Ca release }\end{array}$ & $\begin{array}{c}\text { T/C ratio } \\
\left({ }^{45} \text { Ca release) }\right.\end{array}$ \\
\hline \multirow[t]{4}{*}{ S-14 } & 0 & 4 & $356 \pm 23$ & $0.99 \pm 0.04$ \\
\hline & 1.0 & 4 & $340 \pm 47$ & $2.47 \pm 0.06^{* *}$ \\
\hline & 2.0 & 4 & $364 \pm 31$ & $2.39 \pm 0.33^{*}$ \\
\hline & 5.0 & 4 & $394 \pm 18$ & $2.31 \pm 0.36^{*}$ \\
\hline \multirow[t]{4}{*}{$S-15$} & 0 & 4 & $200 \pm 19$ & $0.99 \pm 0.06$ \\
\hline & 0.02 & 4 & $194 \pm 19$ & $1.02 \pm 0.04$ \\
\hline & 0.2 & 4 & $181 \pm 24$ & $1.13 \pm 0.14$ \\
\hline & 2.0 & 4 & $228 \pm 11$ & $2.37 \pm 0.23^{*}$ \\
\hline \multirow[t]{2}{*}{ S-16 } & 0 & 4 & $470 \pm 19$ & $0.92 \pm 0.03$ \\
\hline & 2.5 & 4 & $494 \pm 41$ & $1.69 \pm 0.17^{*}$ \\
\hline \multirow[t]{3}{*}{ S-17 } & 0 & 4 & $212 \pm 44$ & $1.02 \pm 0.07$ \\
\hline & 0.2 & 4 & $235 \pm 54$ & $1.74 \pm 0.21^{*}$ \\
\hline & 1.0 & 4 & $228 \pm 44$ & $1.32 \pm 0.20$ \\
\hline \multirow[t]{2}{*}{352} & 0 & 8 & $143 \pm 19$ & $1.18 \pm 0.07$ \\
\hline & 5.0 & 4 & $311 \pm 26^{a}$ & $2.24 \pm 0.13^{* *}$ \\
\hline \multirow[t]{3}{*}{358} & 0 & 4 & $345 \pm 37$ & $1.04 \pm 0.04$ \\
\hline & 5.0 & 4 & $653 \pm 81^{a}$ & $2.40 \pm 0.28 *$ \\
\hline & $\begin{array}{l}5.0 \text { (in Eagle } \\
\text { basal medium) }\end{array}$ & 4 & $728 \pm 80^{a}$ & $1.12 \pm 0.07$ \\
\hline \multirow[t]{2}{*}{359} & 0 & 4 & $778 \pm 156$ & $1.05 \pm 0.04$ \\
\hline & 5.0 & 4 & $890 \pm 83$ & $1.85 \pm 0.28$ \\
\hline
\end{tabular}

Values are mean \pm standard error for ${ }^{45} \mathrm{Ca}$ release from the control members of bone pairs and for the treated/control ratios for paired bones with and without parathyroid hormone treatment.

* Values significantly different from $1.00(p<0.05)$.

** Value significantly different from $1.00(p<0.01)$.

${ }^{a}{ }^{45} \mathrm{Ca}$ release significantly greater than with $0 \%$ serum $(p<0.01)$. 


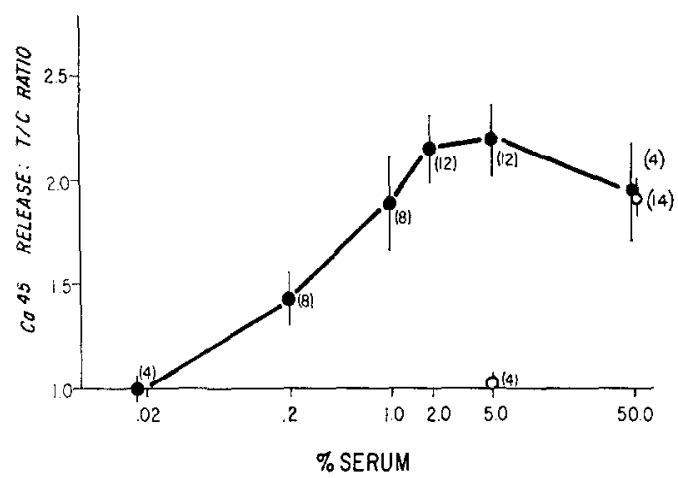

Fig. 1.

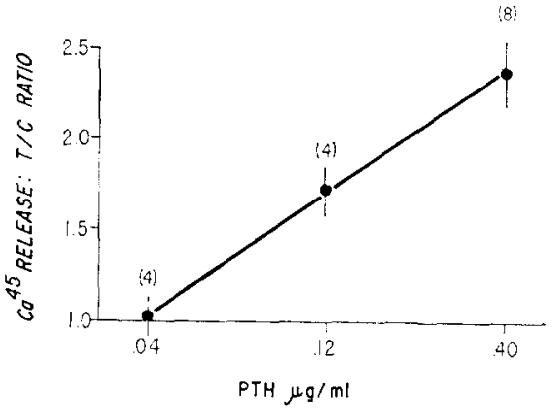

Fig. 2.

Fig. 1.-Relationship between serum content of the medium and the response of embryonic $b$ re to $0.4 \mu \mathrm{g} / \mathrm{ml}(=1 \mathrm{U} / \mathrm{ml})$ PTH. The serum was heat-inactivated PTX rat serum. Values are mean $上$ standard error for the treated/control ratios for paired bones with and without parathyroid hormone treatment. Numbers of bone pairs are in parentheses. C, CMRL 1066; O, Eagle's basal medium.

Fig. 2.-Dose-response curve for PTH-induced ${ }^{45} \mathrm{Ca}$ release in $2 \%$ serum. Media were composed of heat-inactivated PTX rat serum and CMRL 1066 (GIBCO). Values are mean \pm standard error for the treated/control ratios for paired bones with and without parathyroid hormone treatment. Numbers of bone pairs are in parentheses.

TABLE III. ${ }^{45}$ Ca release from embryonic bone and the response to parathyroid hormone (PTH, $0.4 \mu \mathrm{g} / \mathrm{ml})$.

Effects of addition of serum, serum dialysate, or residual material to the culture medium (CMRL 1066-GIBCO).

\begin{tabular}{|c|c|c|c|c|}
\hline \multirow[b]{2}{*}{ Additions } & \multirow[b]{2}{*}{$\mathrm{N}$} & \multicolumn{2}{|c|}{${ }^{45} \mathrm{Ca}$ release $-\mathrm{cpm} / 0.1 \mathrm{ml}$} & \multirow{2}{*}{$\begin{array}{c}{ }^{45} \text { Ca release- } \\
\text { T/C ratio }\end{array}$} \\
\hline & & Control (C) & Treated $(\mathrm{T})$ & \\
\hline None & 4 & $356+22$ & $353 \pm 26$ & $0.99 \pm 0.04$ \\
\hline $5 \%$ PTX rat serum & 4 & $394 \pm 18$ & $928 \pm 173$ & $2.31 \pm 0.36^{*}$ \\
\hline Dialysate & 4 & $392 \pm 32$ & $448 \pm 140$ & $1.16 \pm 0.01 * * a$ \\
\hline Residue & 4 & $465 \pm 46^{b}$ & $1248 \pm 117$ & $2.69 \pm 0.07 * *$ \\
\hline
\end{tabular}

Serum was dialyzed $48 \mathrm{hr}$ at $4^{\circ} \mathrm{C}$ against culture medium; residue was reconstituted with culture medium.

Values are mean \pm slandard error for ${ }^{ \pm 5} \mathrm{Ca}$ release and for the treated/control ratios for paired bones with and without parathyroid hormone treatment.

* Value significantly different from $1.00(p<0.05)$.

** Value significantly different from $1.00(p<0.01)$.

a Value significantly less than $\mathrm{T} / \mathrm{C}$ ratio in medium containing serum or residue $(p<0.01)$.

${ }^{b}{ }^{45} \mathrm{Ca}$ release significantly greater than with $0 \%$ serum $(p<0.05)$. 
The serum constituent required to support the PTII effect

The effects of PTH on ${ }^{45} \mathrm{Ca}$ release were compared in media supplemented with whole serum, serum dialysate, or the protein residue remaining inside the tubing at the termination of the dialysis (Table III). Only the residue fraction significantly increased ${ }^{45} \mathrm{Ca}$ release from the control bones. All three supplements enhanced the response to PTH; however the effect was minimal with the dialysate, suggesting that a protein component was mainly responsible for the enhanced PTH effect.

TABLE IV. Effectiveness of various serum protein fractions in supporting the ${ }^{45} \mathrm{Ca}$ release elicited by 0 . 4 $\mu \mathrm{g} / \mathrm{ml} \mathrm{PTH}$.

\begin{tabular}{|c|c|c|c|c|c|c|}
\hline \multirow{2}{*}{$\begin{array}{l}\text { Exp. } \\
\text { no. }\end{array}$} & \multirow{2}{*}{$\begin{array}{c}\text { Serum } \\
\text { protein fraction }\end{array}$} & \multirow{2}{*}{$\begin{array}{l}\text { Conc. } \\
\mathrm{mg} / \mathrm{ml}\end{array}$} & \multirow[b]{2}{*}{$\mathrm{N}$} & \multicolumn{2}{|c|}{${ }^{45} \mathrm{Ca}$ release $-\mathrm{cpm} / 0.1 \mathrm{ml}$} & \multirow{2}{*}{$\begin{array}{c}{ }^{45} \mathrm{Ca} \text { release- } \\
\mathrm{T} / \mathrm{C} \text { ratio }\end{array}$} \\
\hline & & & & Control (C) & Treated (T) & \\
\hline S-17 & PTX rat albumin & 0.08 & 4 & $200 \pm 46$ & $244 \pm 79$ & $1.14 \pm 0.14$ \\
\hline S-17 & & 0.4 & 8 & $243 \pm 44$ & $477 \pm 178$ & $1.76 \pm 0.26 *$ \\
\hline$S-16$ & & 1.0 & 4 & $429 \pm 14$ & $674 \pm 138$ & $1.61 \pm 0.28$ \\
\hline S-14 & & 2.0 & 4 & $392 \pm 32$ & $842 \pm 140$ & $2.15 \pm 0.29 *$ \\
\hline 358 & Bovine albumin & 2.0 & 4 & $616 \pm 171$ & $1054 \pm 347$ & $1.79 \pm 0.25 *$ \\
\hline \multirow[t]{2}{*}{359} & fraction $V$ & 2.0 & 4 & $1201 \pm 383$ & $1819 \pm 505$ & $1.60 \pm 0.13^{*}$ \\
\hline & & & 8 & & & $1.69 \pm 0.14 * *$ \\
\hline 358 & FFA-poor & 2.0 & 4 & $422 \pm 55$ & $753 \pm 187$ & $1.74 \pm 0.36$ \\
\hline 359 & bovine albumin & 2.0 & 4 & $854 \pm 142$ & $1140 \pm 321$ & $1.27 \pm 0.14$ \\
\hline \multirow[t]{2}{*}{ S-17 } & fraction $V$ & 2.0 & 4 & $319 \pm 110$ & $575 \pm 218$ & $1.88 \pm 0.42$ \\
\hline & & & 12 & & & $1.63 \pm 0.19 * *$ \\
\hline 358 & Crystalline & 2.0 & 4 & $466 \pm 116$ & $609 \pm 124$ & $1.37 \pm 0.19$ \\
\hline \multirow[t]{2}{*}{359} & bovine albumin & 2.0 & 4 & $719 \pm 176$ & $875 \pm 238$ & $1.18 \pm 0.10$ \\
\hline & & & 8 & & & $1.29 \pm 0.10^{*}$ \\
\hline 359 & Human albumin & 2.0 & 4 & $750 \pm 73$ & $983 \pm 109$ & $1.32 \pm 0.15$ \\
\hline S-16 & $\begin{array}{l}\text { Bovine alpha } \\
\text { globulin }\end{array}$ & 0.4 & 4 & $352 \pm 17$ & $334 \pm 42$ & $0.97 \pm 0.04$ \\
\hline S-16 & $\begin{array}{l}\text { Bovine beta } \\
\text { globulin }\end{array}$ & 0.4 & 4 & $339 \pm 14$ & $338 \pm 12$ & $1.00 \pm 0.06$ \\
\hline$S-16$ & $\begin{array}{l}\text { Bovine gamma } \\
\text { globulin }\end{array}$ & 0.4 & 4 & $390 \pm 36$ & $357 \pm 23$ & $0.95 \pm 0.02$ \\
\hline
\end{tabular}

Values are mean \pm standard error for ${ }^{45} \mathrm{Ca}$ release and for the treated/control ratios for paired bones with and without parathyroid hormone treatment.

* Value significantly different from $1.00(p<0.05)$.

** Value significantly different from $1.00(p<0.01)$. 
Data from studies comparing the relative effectiveness of several serum protein fractions are included in Table IV. All of the albumin fractions tested could support a PTH effect when the proteins were present at a concentration of $2.0 \mathrm{mg} / \mathrm{ml}$ of medium. PTX ral albumin was the most effective in enhancing the ${ }^{45} \mathrm{Ca}$ release in response to $\mathrm{PTH}$; bovine fraction $\mathrm{V}$ preparations were

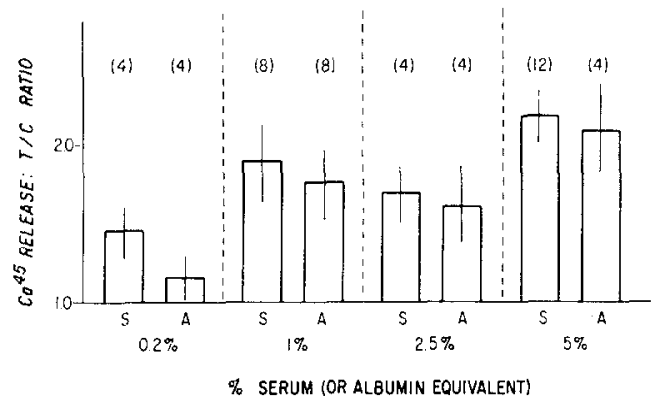

Fig. 3.-Comparisons of the capacity of PTX rat serum $(S)$ with that of the albumin fraction $(A)$ to support the response to $0.4 \mu \mathrm{g} / \mathrm{ml}$ PTH. Media were composed of CMRL 1066 (GIBCO) and the indicated amount of heat-inactivated serum or the equivalent amount of albumin from the same batch of serum. The amount added was based on an estimated $4 \mathrm{~g}$ albumin/100 gram rat serum. Values are mean \pm standard error for the treated/control ratios for paired bones with and without parathyroid hormone treatment. $0.08 \mathrm{mg} / \mathrm{ml}$ albumin was significantly less effective than $0.2 \%$ serum $(p<0.05)$. The responses in $1 \%$ serum vs $0.4 \mathrm{mg} / \mathrm{ml}$ albumin, in $2.5 \%$ serum vs $1 \mathrm{mg} / \mathrm{ml}$ albumin, and in $5 \%$ serum vs $2 \mathrm{mg} / \mathrm{ml}$ albumin did not differ significantly $(p>0.05)$. Numbers of bone pairs are in parentheses.

somewhat less effective; crystalline bovine and human were the least effective of the serum albumins tested. Serum alpha, beta and gamma globulin fractions added in amounts approximating their concentrations in a medium containing 5 per cent serum failed to support a P'TH response. The data shown in Fig. 3 provide further evidence that albumin is responsible for the effect of serum. Amounts of albumin equivalent to those contained in 1.0 to 5.0 per cent serum were as effective as the whole serum in supporting the P'TH effect.

Five other substances were tested for their capacity to support the response to PTH (Table V). Gelatin has been reported to increase the activity of injected PTH, possibly by delaying its absorption [19, 24]. In tissue culture gelatin had no significant effect. Histone, which at low concentrations has effects on mitochondrial function resembling those of parathyroid hormone [1], was ineffective in tissue culture. A concentration of heparin previously shown to potentiate effects of parathyroid hormone on newborn mouse calvaria in culture $[10]$ was ineffective in the present culture system using embryo- 
TABLE V. The effect of addition of gelatin, heparin, insulin, calf thymus histone or ovalbumin on the ${ }^{45} \mathrm{Ca}$ release induced by parathyroid hormone $(P T H, 0.4 \mu \mathrm{g} / \mathrm{ml})$ in a synthetic medium (CMRL 1066-GIBCO).

\begin{tabular}{|c|c|c|c|c|c|c|}
\hline \multirow{2}{*}{$\begin{array}{l}\text { Fixp. } \\
\text { no. }\end{array}$} & \multirow{2}{*}{$\begin{array}{l}\text { Material } \\
\text { added }\end{array}$} & \multirow{2}{*}{$\begin{array}{c}\text { Conc. } \\
\mathrm{U} \text { or } \mathrm{mg} / \mathrm{ml}\end{array}$} & \multirow[b]{2}{*}{$\mathbf{N}$} & \multicolumn{2}{|c|}{${ }^{45} \mathrm{Ca}$ release-cpm/0.1 ml } & \multirow{2}{*}{$\begin{array}{c}{ }^{45} \text { Ca release } \\
\mathrm{T} / \mathrm{C} \text { ratio }\end{array}$} \\
\hline & & & & Control (C) & Treated $(\mathrm{T})$ & \\
\hline 359 & Gelatin & $2.0 \mathrm{mg} / \mathrm{ml}$ & 4 & $777 \pm 175$ & $796 \pm 150$ & $1.05 \pm 0.04$ \\
\hline S-14 & Heparin & $10 \mathrm{U} / \mathrm{ml}$ & 4 & $332 \pm 23$ & $360 \pm 29$ & $1.08 \pm 0.03$ \\
\hline S-15 & Insulin & $1 \mathrm{~L} / \mathrm{ml}$ & 3 & $148 \pm 1$ & $153 \pm 10$ & $1.03 \pm 0.03$ \\
\hline \multirow[t]{2}{*}{ S-17 } & Calf thymus & & & & & \\
\hline & histone & $2.0 \mathrm{mg} / \mathrm{ml}$ & 4 & $228 \pm 60$ & $220 \pm 52$ & $0.98 \pm 0.04$ \\
\hline S-17 & Ovalbumin & $2.0 \mathrm{mg} / \mathrm{ml}$ & 4 & $204 \pm 35$ & $384 \pm 114$ & $1.77 \pm 0.31$ \\
\hline
\end{tabular}

Values are mean \pm standard error for ${ }^{45} \mathrm{Ca}$ release and for the treated/control ratios for paired bones with and without parathyroid hormone treatment.

nic rat limb bones. Insulin failed to support the PTH effect. Ovalbumin did support an enhanced ${ }^{45} \mathrm{Ca}$ release from PTH-treated bones; however, the magnitude of the response was highly variable.

Effect of proteins on the control response

It has been noted above that serum, as well as the non-dialyzable residue of serum could increase ${ }^{45} \mathrm{Ca}$ release from bone cultures in the absence of added PTII. The effect of $4 \mathrm{mg} / \mathrm{ml}$ of several serum proteins on ${ }^{45} \mathrm{Ca}$ release from control bones in medium CMRL 1066 is shown in Table VI. Fraction V consistently increased ${ }^{45} \mathrm{Ca}$ release, even after a tenfold dilution. The $\mathrm{Ca}^{45}$ release elicited by the other serum albumin preparations and the globulin fractions was variable and less marked. Ovalbumin did not enhance the control ${ }^{45} \mathrm{Ca}$ release, nor did it affect the ${ }^{45} \mathrm{Ca}$ releasing properties of the albumin fractions tested when these were added together.

Since albumin has a large calcium-binding capacity [14], it was considered to be possible that the increased ${ }^{45} \mathrm{Ca}$ in the medium could have resulted from a binding of the medium calcium by albumin, followed by a release of calcium from bone to reestablish equilibrium for free calcium. Equilibrium dialysis in medium CMRL 1066 with ${ }^{45} \mathrm{Ca}$ added showed a 10 per cent higher final ${ }^{45} \mathrm{Ca}$ content in the compartment which contained $4 \mathrm{mg} / \mathrm{ml}$ albumin (Table VII). 
TABLE VI. Capacity of serum proteins to increase calcium release from bone in tissue culture medium CMRL 1066 (GIBCO) in the absence of parathyroid hormone.

\begin{tabular}{|c|c|c|c|c|c|c|c|}
\hline \multirow{2}{*}{$\begin{array}{l}\text { Exp. } \\
\text { no. }\end{array}$} & \multirow{2}{*}{$\begin{array}{l}\text { Serum protein } \\
\text { fraction }\end{array}$} & \multirow{2}{*}{$\begin{array}{l}\text { Conc. } \\
\mathrm{mg} / \mathrm{ml}\end{array}$} & \multirow[b]{2}{*}{$\mathbf{N}$} & \multicolumn{2}{|c|}{${ }^{45} \mathrm{Ca}$ release-cpm $/ 0.1 \mathrm{ml}$} & \multirow{2}{*}{$\begin{array}{c}{ }^{45} \text { Ca release } \\
\mathrm{T} / \mathrm{C} \text { ratio }\end{array}$} & \multirow{2}{*}{$\begin{array}{l}\text { Total Ca }{ }^{a} \\
\text { T/C ratio }\end{array}$} \\
\hline & & & & Control (C) & Treated $(\mathrm{T})$ & & \\
\hline S-11 & \multirow{3}{*}{$\begin{array}{l}\text { Albumin } \\
\text { (fraction V, } \\
\text { bovine) }\end{array}$} & 0.4 & 4 & $300 \pm 66$ & $440 \pm 111$ & $1.40 \pm 0.14$ & $1.05 \pm 0.05$ \\
\hline \multirow[t]{2}{*}{$\mathrm{S}-12$} & & \multirow[t]{2}{*}{0.4} & 4 & \multirow{2}{*}{$293 \pm 10$} & \multirow{2}{*}{$427 \pm 45$} & $1.49 \pm 0.23$ & \multirow{2}{*}{$1.11 \pm 0.06$} \\
\hline & & & 8 & & & $1.45 \pm 0.12 *$ & \\
\hline S-10 & Albumin & 4.0 & 4 & $125 \pm 18$ & $213 \pm 65$ & $1.65 \pm 0.34$ & $1.08 \pm 0.01$ \\
\hline$S-11$ & (fraction $\mathrm{V}$ & 4.0 & 4 & $287 \pm 59$ & $532 \pm 183$ & $1.72 \pm 0.44$ & $1.00 \pm 0.02$ \\
\hline \multirow[t]{2}{*}{$\mathrm{S}-12$} & \multirow{2}{*}{ bovine) } & \multirow[t]{2}{*}{4.0} & 4 & \multirow{2}{*}{$280 \pm 39$} & \multirow{2}{*}{$556 \pm 34$} & $1.87 \pm 0.21^{* *}$ & \multirow{2}{*}{$0.97 \pm 0.06$} \\
\hline & & & 12 & & & $1.79 \pm 0.16^{* *}$ & \\
\hline S-11 & Albumin & 1.0 & 4 & $318 \pm 67$ & $114 \pm 104$ & $1.21 \pm 0.11$ & $1.05 \pm 0.05$ \\
\hline \multirow[t]{2}{*}{ S-12 } & \multirow{2}{*}{$\begin{array}{l}\text { (crystalline, } \\
\text { bovine) }\end{array}$} & \multirow[t]{2}{*}{4.0} & 4 & \multirow[t]{2}{*}{$270 \pm 26$} & \multirow[t]{2}{*}{$358 \pm 34$} & $1.34 \pm 0.12$ & \multirow[t]{2}{*}{$0.97 \pm 0.04$} \\
\hline & & & 8 & & & $1.29 \pm 0.08^{*}$ & \\
\hline S-11 & Albumin & 4.0 & 4 & $313 \pm 38$ & $392 \pm 46$ & $1.23 \pm 0.08$ & $1.00 \pm 0.03$ \\
\hline \multirow[t]{2}{*}{ S-12 } & (FFA-poor & \multirow[t]{2}{*}{4.0} & 4 & \multirow[t]{2}{*}{$318 \pm 7$} & \multirow[t]{2}{*}{$318 \pm 4$} & $1.00 \pm 0.07$ & \multirow[t]{2}{*}{$1.02 \pm 0.04$} \\
\hline & $\begin{array}{l}\text { fraction } v \text {, } \\
\text { bovine) }\end{array}$ & & 8 & & & $1.12+0.07$ & \\
\hline S-11 & $\begin{array}{l}\text { Albumin } \\
\text { (human) }\end{array}$ & 4.0 & 4 & $289 \pm 80$ & $330 \pm 91$ & $1.16+0.11$ & $1.08 \pm 0.11$ \\
\hline$S-11$ & $\begin{array}{l}\text { Albumin } \\
\text { (PTX rat) }\end{array}$ & 4.0 & 4 & $238 \pm 44$ & $300 \pm 69$ & $1.24 \pm 0.08$ & $1.03 \pm 0.02$ \\
\hline $\mathrm{S}-8$ & Globulin & 4.0 & 4 & $171 \perp 27$ & $198 \perp 32$ & $1.16 \perp 0.05^{* *}$ & $0.88 \perp 0.09$ \\
\hline$S-10$ & (alpha, bovine) & 4.0 & 4 & $127 \pm 8$ & $158 \pm 13$ & $1.25 \pm 0.06^{* *}$ & $1.00 \pm 0.11$ \\
\hline S-8 & $\begin{array}{l}\text { Globulin } \\
\text { (beta, bovine) }\end{array}$ & 4.0 & 4 & $147+23$ & $181+25$ & $1.24+0.05 *$ & $0.94+0.10$ \\
\hline S-8 & Globulin & 4.0 & 4 & $155 \pm 16$ & $201 \pm 73$ & $1.28 \pm 0.18$ & $0.83 \pm 0.08$ \\
\hline S-10 & (gamma, bovine) & 4.0 & 4 & $119 \pm 21$ & $115 \pm 12$ & $1.00 \pm 0.10$ & $1.03 \pm 0.07$ \\
\hline
\end{tabular}

Values are mean $\perp$ standard error for $\mathrm{Ca}^{45}$ release and for the treated/control ratios for paired bones with and without serum proteins in the medium.

* Value significantly different from $1.00(p<0.05)$.

** Value significantly different from $1.00(p<0.01)$.

${ }^{a}$ Ratio of calcium content in the media with and without protein, measured at the termination of the incubation. 
TABLE VII. Equilibrium dialysis study to evaluate the significance of calcium binding for the ${ }^{45} \mathrm{Ca}$ release produced by albumin.

Conditions: $37^{\wedge} \mathrm{C}, 5 \% \mathrm{CO}_{2}$ in air, CMRL 1066, $72 \mathrm{hr}$.

\begin{tabular}{|c|c|c|c|}
\hline & Inside (I) & Outside $(O)$ & $1 / 0$ \\
\hline \multicolumn{4}{|l|}{ Initial } \\
\hline${ }^{45} \mathrm{Ca}$ & ++ & $\because$ & (1) \\
\hline $\begin{array}{l}\text { Albumin } \\
\text { (bovine serum } \\
\text { fraction } V \text { ) }\end{array}$ & $4.0 \mathrm{mg} / \mathrm{ml}^{u}$ & 0 & \\
\hline \multicolumn{4}{|l|}{ Final } \\
\hline${ }^{45} \mathrm{Ca}(\mathrm{cpm} / \mathrm{ml})$ & 27,000 & 24,500 & $(1.10)$ \\
\hline Albumin & $4.2 \mathrm{mg} / \mathrm{ml}^{b}$ & 0 & \\
\hline
\end{tabular}

Histologic studies

Examination of the cultivated bones revealed that there was poor cell survival in the chemically-defined media and in media supplemented with small amounts of protein (less than $1 \mathrm{mg} / \mathrm{ml}$ ). In media supplemented with 5 per cent serum, PTH produced resorption of the bone matrix accompanied by the appearance of osteoclasts and large numbers of fibroblasts. Resorption and osteoclasts were just as apparent in media containing $2 \mathrm{mg} / \mathrm{ml}$ serum albumin or ovalbumin as in 5 per cent serum, but the fibroblastic proliferation in response to the hormone was not as marked in the albumin-supplemented media. These PTH-induced changes were seen in media containing as little as $0.4 \mathrm{mg} / \mathrm{ml}$ albumin, despite the poor cellularity. No PTH effects were seen with 1066 alone.

\section{DISCUSSION}

Although organ cultures of embryonic bone rudiments can be maintained and may even grow in chemically-defined media $\lceil 3,12,27\rceil$, serum has always been a constituent of media in studies of the effects of substances which enhance bone resorption in vitro $[6,9,10,21]$. A culture medium without serum which would support the resorptive response to parathyroid hormone was sought because it could provide a better-defined environment for metabolic studies and might eliminate some of the variability in response encountered with media containing large amounts of serum. None of the eight 
commercially available media tested was adequate without protein supplement. Even the most highly enriched media tested (CMRL 1066, McCoy 5A, NCTC 109) could not support bone resorption in response to purified PTH. Crude paralhyroid exlract (PTE) stimulated ${ }^{45} \mathrm{Ca}$ release in three media: Waymouth 752/1 plus cofactors, Difco 1066 and C.MRL 1066; however, the non-hormonal proteins in the parathyroid extract may have played a role in this response. No response could be obtained to a purified parathyroid hormone preparation ( $\mathrm{P}^{\prime} \mathrm{TH}$ ) in medium CMRL 1066. However, with the addition of as little as 0.2 per cent of serum, this medium could support a response to PTH. A maximal response could be obtained with 1 to 2 per cent serum, in contrast to the 50 per cent concentration of serum required in the Eagle Basal Medium used in previous studies $[8,20-23]$.

Studies of various serum fractions indicated that a partially purified albumin fraction supplied the same factor(s) supporting bone resorption as did whole serum. The various serum globulin fractions as well as gelatin, histone, heparin and insulin were ineffective. The mechanism of the effect of albumin is not known. It does not seem likely that the simple provision of amino acids for nutrition is responsible, since the chemically defined media contained high concentrations of amino acids, as did the globulin fractions. The colloid osmotic effect of albumin could play a role, but this should have been obtained with other proteins. A major difference between albumins and other proteins lies in their isoelectric point and availability of protons. The binding properties of albumins might play a significant role in several ways. Albumin can bind considerable quantities of cation [14]. However, unless the calcium-binding properties of albumin were remarkably altered by parathyroid hormone, this could not explain the present results. While the possibility that parathyroid hormone alters ion binding by bovine albumin has been suggested on the basis of studies of calcium and magnesium release from dead bone $[11,18]$, these studies were done with large amounts of crude parathyroid extract, and produced only small increments in ion release. The eflects we have seen wilh PTH on living bone do nol occur with dead bone in a variety of media.

Albumin, and to a lesser degree, ovalbumin have been shown to bind a variety of organic substances, especially anions [17]. Of these, only free fatty acid has been examined in our system thus far, and it does not appear to be involved. Vitamin $\mathrm{A}$ and vitamin $\mathrm{D}$ can enhance bone resorption and the latter may play a permissive role in the parathyroid response [21]. However, these substances are bound to globulins as well as to albumin fractions $[2,5]$. The preparations used in the present study did not separate pre- 
albumin from albumin. The role of the pre-albumin should be examined further. The effect cannot be ascribed to contamination with parathyroid and thyroid hormones, since serum and albumin obtained from parathyroidectomized rals and serum from thyroparathyroidectomized rats were as effective as human or bovine serum. Moreover, the effect of serum was largely to support a parathyroid response rather than to stimulate bone resorption directly.

A number of the substances tested could stimulate some increase in ${ }^{45} \mathrm{Ca}$ release in the absence of PTH. This effect was not consistently related to their ability to support the PTH response. Calcium binding probably does not account for the direct albumin effects noted. On the basis of Carr's analysis of calcium binding by albumin [4], binding of 0.8 to $1.6 \mathrm{mg} \mathrm{Ca} / \mathrm{g}$ of protein would be expected in the present system. This would amount to only $0.3 \mu \mathrm{g}$ of calcium per culture bound by the smallest amount of bovine fraction $V$ which was active in the present system $(0.4 \mathrm{mg} / \mathrm{ml})$, while the observed increase in ${ }^{45} \mathrm{Ca}$ release from bone was calculated to represent 2 to $5 \mu \mathrm{g}$ of calcium.

Fell and Weiss [7] reported that immunological reactions between the serum and the tissue might stimulate bone resorption. They found that this phenomenon was inhibited by heating the sera to $60^{\circ} \mathrm{C}$. In preliminary experiments we found that heat inactivation did not abolish the ability of serum either to produce control resorption or to support the PTH response, and therefore used such heat-inactivated sera subsequently. It is possible that some of our earlier observations $[21]$ of marked differences in effects of serum on control resorption could be ascribed to immunologic reactions.

It is not certain whether the factors responsible for direct stimulation of bone resorption and enhancement of PTH effects in the present study are acting as general nutrients or as specific co-factors for bone resorption. The histologic observation that the cellularity of cultures containing serum was better preserved suggests that albumin may simply act as a nutrient or material to prevent dedifferentiation and deterioration of cells in culture, possibly by preventing the loss of coating proteins. On the other hand, the present culture system is one in which resorption appears to be the major cellular activity so that the appearance of more and better preserved cells could result from a specific stimulation of bone resorption. This appears to be the case in PTH-stimulated bones. Whatever their nature, non-parathyroid factors regulating bone resorption could have important physiological and pathological roles, particularly since some control of bone resorption appears to persist after the removal of thyroids and parathyroids. 


\section{S UMMARY}

1. Several chemically-defined media were tested for their capacity to support parathyroid hormone-induced ${ }^{45} \mathrm{Ca}$ release from embryonic bone. None was completely satisfactory.

2. A medium consisting of 2 per cent serum in CMRL 1066 would support the parathyroid hormone effect as well as did media containing 50 per cent serum plus 50 per cent CMRL 1066 or 50 per cent Eagle Basal Medium.

3 . The albumin content of rat serum could be substituted for the whole serum without loss of the observed parathyroid hormone effect. Different albumin preparations varied in their capacity to support the response. Serum globulins, gelatin, histone, heparin or insulin could not replace serum.

4. A number of substances enhanced ${ }^{45} \mathrm{Ca}$ release in the absence of parathyroid hormone. Bovine albumin (fraction $V$ ) was the most effective preparation tested.

The authors wish to thank Dr William Au for supplying the purified parathyroid hormone, and Emil Paul Hornyak, Ingrid Niemann and Amy Doty for technical assistance. The work done at the University of Michigan was made possible by the generous assistance of Dr Theodore M. Brody. The studies at Michican were carried out in the Central Tissue Culture Facilities. We thank the Tissue Culture Committee for permission to use these facilities and especially Dr Peter Ludovici for his inlerest and assistance.

\section{REFERENCES}

1. Aurbach, G., Houston, B. and Potts, J., Jr., Biochem. Biophys, Res. Comm. 20,592 (1965).

2. Bexnunin, H., in H. Pfaters (ed.), Protides of the Biological Fluids, p. 58. Fisevier, New York, 1961.

3. Biggers, J. D., Gwatkin, R. B. L. and Heyner, S., Exptl Cell Res. 25, 41 (1961).

4. Carr, C. W., Arch. Biochem. Biophys. 46, 424 (1953).

5. Cinen, P. S., Jr. and Lane, K., Arch. Biochem. Biophys. 112, 70 (1965).

6. Fell, H. B. and Mellanby, E., J. Physiol. 116, 320 (1952).

7. Fell, H. B. and Weiss, L., J. Exptl Med. 121, 551 (1965).

8. Friedman, J. and Raisz, L. G., Science 150, 1465 (1965).

9. Gatllard, P. J., in R. O. Greep and R. V. Talmage (ed.), The Parathyroids, p. 94. C. C. Thomas, Springfield, 1961.

10. Goldhaber, P., Science 147, 407 (1965).

11. Gordon, G. S., Acta Endoc. 44, 481 (1963).

12. Gorham, L. W. and Waymouth, C., Proc. Soc. Expll Biol. Med. 119, 287 (1965).

13. Gornall, A. G., Bardwill, C. J. and David, M. M., J. Biol. Chem. 177, 751 (1949).

14. Hastings, A. B. and McLean, F. C., J. Biol. Chem, 108, 285 (1935).

15. Hawker, C. D., Glass, J. D and Rasmussen, H., Biochem. 5, 344 (1966).

16. Kingsley, G. R. and Robnett, O., Am. J. Clin. Pathol. 29, 171 (1958).

17. Klotz, I. M. and Urquhart, J. M., J. Am. Chem. Soc. 71, 1597 (1949).

18. Martindale, L. and Heaton, F. W., Biochem. J. 97, 440 (1965).

19. Munson, P. L., in R. O. Greep and R. V. Talmage (eds.), The Parathyroids, p. 94. C. C. Thomas, Springfield, 1961. 
20. Raisz, L. G., Nature 197, 1015 (1963).

21. - J. Clin. Invest. 44, $103(1965)$.

22. — Proc. Soc. Exptl Biol. Med. 119, 614 (1965).

23. Raisz, L. G., Au, W. Y. W. and Stern, P. H., in P. J. Gaillard, R. V. Talmage and A. M. Bupy (eds.), The Parathyroid Glands, p. 37. Univ, of Chicago Press, Chicago, 1965.

24. Rasmussen, H., J. Biol. Chem. 234, 547 (1959).

25. Schwert, G. W., J. Am. Chem. Soc. 79, 139 (1957).

26. Sri Ram. J. and Maurer, P. H., Arch. Biochem. Biophys. 76, 28 (1958).

27. Trafond, M. F. and Winte, A. A., Proc. Soc. Exptl Biol. Med. 117, 536 (1964). 